DOI:

\title{
Perancangan Sistem Informasi Akuntansi Harga Pokok Produksi Pada Distro Viking Cimahi Dengan Menggunakan Software Microsoft Visual Basic 2008 Dan Database MySQL \\ Sheylla Febryani ${ }^{1}$, Dony Waluya Firdaus ${ }^{2}$ \\ TU SLB Negeri A Kota Bandung \\ Jl. Pajajaran No. 50 \\ Email: sheyllajunong11@gmail.com
}

\section{Keywords: \\ Designing, Accounting Information Systems, Cost of Production.}

\section{Kata Kunci:}

Perancangan, Sistem Informasi Akuntansi, Harga Pokok Produksi.

\begin{abstract}
Viking Distro cimabi conducts business in manufacturing companies that produce $t$-shirts for Persib bandung soccer players, researchers conducted a survey and found that the accounting records system that is currently running is still manual, therefore researchers conducted research with the title "Designing a Cost of Production Accounting Information System (HPP) on the Viking Cimahi Distro using Mcrosoft Visual Basic 2008 and the MYSQ Database".
\end{abstract}

Researchers conduct research using research design that is descriptive research, the type of research using academic research, data using quantitative data, while the research method is survey and conduct interview interviews to collect data according to the surveyed, while researchers in designing using contex charts, data flow diagram and flowchart system The researcher conducts research by making a system of accounting information on the cost of production, with the design can provide input related to the title that the researcher discussed.

\section{Abstrak}

Distro Viking cimabi melakukan usaba dibidang perusahaan manufaktur yang memproduksi kaos pemain sepak bola persib bandung, peneliti melakukan survey dan ditemukan babwa system pencatatan akuntansi yang sedang berjalan masib bersifat manual, maka peneliti melakukan penelitian dengan judul "Perancangan Sistem Informasi Akuntansi Harga Pokok Produksi(HPP) pada Distro Viking Cimahi menggunakan Mcrosoft Visual Basic 2008 dan Database MYSQ".

Peneliti melakukan penelitian menggunakan desain penelitian yaitu penelitian deskritif, jenis penelitian menggunakan penelitian akademik,data menggunakan da data kuantutatif, sedangkan metode penelitian yaitu survey dan melakukan dektik wawancara untuk mengumpulkan data sesuai dengan yang disurvey, sedangkan peneliti dalam melakukan perancangan menggunakan diagram contexs, data flow diagram dan flowchart system Peneliti melakukan penelitian dengan membuat perancangan sistem informasi akuntansi harga pokok produksi, dengan perancangan tersebut dapat memberikan masukan terkait dengan judul yang peneliti bahas. 
Nama Penulis : Dony Waluya Firdaus, Sheylla Febryani

Judul : Perancangan Sistem Informasi Akuntansi Harga

Pokok Produksi Pada Distro Viking Cimahi

Dengan Menggunakan Software Microsoft Visual

Basic 2008 Dan Database MySQL
Jurnal @ is The Best

Vol. 04 No. 01. Juni 2019: Hal 366-380

P-ISSN : 2252-9853

\section{Pendahuluan}

\section{Latar Belakang}

Perkembangan ilmu pengetahuan dan pembangunan saat ini untuk semua perusahaan/instalasi pemerintah atau swasta diharapkan untuk menyesuaikan dengan perkembangan teknologi informasi sehingga dapat menghasilkan informasi lebih tepat dan akurat. Teknologi informasi telah banyak berperan dalam membantu kegiatan operasional di perusahaan, seperti di perusahaan dagang, jasa \& manufaktur. Dengan sudah adanya teknologi informasi pada suatu perusahaan maka dapat membantu untuk pengolah data agar menjadi sebuah informasi.

Pada perusahaan manufaktur terdapat perbedaan dari perusahaan jasa \& dagang, dimana dalam perusahaan manufaktur bidang usahanya yaitu mengelolah bahan baku menjadi bahan setengah jadi/barang jadi yang siap untuk diperjual belikan. Dalam menentukan harga pokok yang tepat di perusahaan mannufaktur sangatlah penting.

Harga pokok merupakan dasar penentu harga jual suatu barang yang telah dibuat di perusahaan manufaktur, untuk membandingkan besaran antara biaya produksi dan keuntungan yang didapatkan. Harga pokok ialah kumpulan biaya produksi yang terdiri dari bahan baku langsung, tenaga kerja langsung dan biaya overhead pabrik ditambah persediaan produk dalam proses awal dan kemudian dikurangi persediaan produk dalam proses akhir.

\section{Identifikasi Masalah}

1) Bagaimana Sistem Informasi Akuntansi Harga Pokok Produksi berdasarkan pesanan pada Distro Viking Cimahi.

2) Bagaimana Perancangan Sistem Informasi Akuntansi Harga Pokok Produksi berdasarkan pesanan pada Distro Viking Cimahi menggunakan software Microsoft Visual Basic 2008.

\section{Batasan Masalah}

1) Penulis membatasi hanya pada Sistem Informasi Akuntansi Harga Pokok produksi dengan metode berdasarkan pesanan, dengan metode harga pokok pesanan variabel costing.

2) Perancangan Sistem Informasi Akuntansi Harga Pokok Produksi dengan menggunakan software Microsoft Visual Basic 2008 dan database MySQL.

\section{Kerangka Teoritis Dan Pengembangan Hipotesis}

\section{Perancangan}

Definisi perancangan menurut Azhar Susanto "perancangan adalah kemampuan untuk membuat beberapa alternatif pemecahan masalah"[1]. Langkah awal dalam membuat sistem adalah perancangan dari sistem tersebut, menurut Muhamad Subhan dalam bukunya yang berjudul Analisa Perancangan Sistem mengungkapkan bahwa: "perancangan adalah proses pengembangan spesifikasi baru berdasarkan rekomendasi hasil analisis sistem".[2]

Berdasarkan definisi-definisi diatas penulis dapat menyimpulkan bahwa perancangan adalah kemampuan seseorang yang bertujuan untuk memecahkan suatu masalah. 
Nama Penulis : Dony Waluya Firdaus, Sheylla Febryani

Judul : Perancangan Sistem Informasi Akuntansi Harga

Pokok Produksi Pada Distro Viking Cimahi

Dengan Menggunakan Software Microsoft Visual

Basic 2008 Dan Database MySQL
Jurnal @ is The Best

Vol. 04 No. 01. Juni 2019: Hal 366-380

P-ISSN : 2252-9853

\section{Sistem}

Definisi sistem menurut Azhar Susanto, "sistem adalah kumpulan/group dari subsistem/bagian/komponen apapun baik phisik ataupun non phisik yang saling berhubungan satu sama lain dan bekerja sama secara harmonis untuk mecapai satu tujuan tertentu"[1].

Definisi lain menurut Tata Sutarbi "suatu kumpulan atau himpunan dari unsur komponen, variabel yang teroganisasi, saling berinteraksi saling tergantung satu sama lain dan terpadu"[3].

Berdasarkan definisi-definisi di atas, maka penulis menyimpulkan bahwa sistem adalah kumpulan yang saling berhubungan dan dapat saling berinteraksi sehingga dapat tujuan tertentu.

\section{Informasi}

Definisi informasi menurut Tata Sutarbi "informasi adalah data yang telah diklsifikasikan atau diolah diinterpretasikan untuk digunakan dalam proses pengembangan keputusan"[3].

Definisi lain dari informasi menurut Unika Soegijapranata "informasi adalah data yang diorganisasikan dan telah memiliki kegunaan dari manfaat"[4].

Berdasarkan definisi informasi di atas, penulis menyimpulkan bahwa informasi adalah kumpulan-kumpulan data yag telah diolah yang akan menghasilkan menjadi suatu informasi yang bermanfaat".

\section{Sistem Informasi}

Definisi sistem informasi menurut Tatab Sutarbi, "Sistem informasi adalah suatu sistem di dalam suatu organisasi yang mempertemukan kebutuhan pengolahan transaksi harian yang mendukung fungsi operasi organisasi yang bersifat manajerial dengan kegiatan laporan-laporan yang dipertemukan oleh pihak luar tertentu'[3].

Definisi lain menurut Azhar Susanto dalam bukunya yang berjudul Sisten Informasi Manajemen definisi dari sistem informasi adalah sebagai berikut: "Sistem informasi adalah kumpulan dari sub-sub sistem baik phisik maupun non phisik yang saling berhubungan satu sama lain dan bekerjasama secara harmonis untuk mencapai satu tujuan yaitu mengelola data menjadi informasi yang berguna"[1].

Berdasarkan definisi di atas, penulis dapat menyimpulkan bahwa sistem informasi merupakan sebuah sistem yang saling berhubungan serta dapat memproses transaksi dalam organisasi guna menghasilkan laporan dan informasi.

\section{Akuntansi}

Definisi akuntansi menurut Lilis Puspitawi dan Sri Dewi Anggadini, "proses yang terdiri dari identifikasi pengukuran dan pelaporan informasi akuntansi”[5]. Definisi lain menurut Marshall B. Rommey dan paul Jhon Steinbart; "untuk menyediakan informasi yang berguna bagi para pengambil keputusan"'[6].

Berdasarkan definisi di atas, maka penulis menyimpulkan bahwa akuntansi adalah suatu proses yang didefinisikan bagi para pengambil keputusan untuk mencapai informasi akuntansi.

\section{Metode Pencatatan Akuntansi}

Definisi metode Pencatatan Akuntansi menurut Bastian "ada dua metode yaitu metode pencatatan Cash Basic dan Accural Basic menjelaskan Cash Basic accounting atau akuntansi berbasis kas, yaitu menetapkan bahwa pencatatan transaksi ekonomi hanya dilakukan apabila transaksi tersebut merencanakan perubahan pada kas. Accrual basic accounting (akuntansi akural), yaitu, dasar akuntansi yang mengakhiri akuntansi dan dasar peristiwa tersebut terjadi dan bukan hanya pada saat kas atau setara kas diterima atau dibayar"'[7]. 
Nama Penulis : Dony Waluya Firdaus, Sheylla Febryani

Judul : Perancangan Sistem Informasi Akuntansi Harga

Pokok Produksi Pada Distro Viking Cimahi

Dengan Menggunakan Software Microsoft Visual

Basic 2008 Dan Database MySQL
Jurnal @ is The Best

Vol. 04 No. 01. Juni 2019: Hal 366-380

P-ISSN : 2252-9853

Definisi lain dari metode pencatatan akuntansi akural menurut Ikatan Akuntansi Indonesia (IAI), "adalah dasar akural adalah dasar pencatatan transaksi diakui pada saat kejadian (dan bukan saat kas atau setara kas diterima atau dibayar) dan dicatat akuntansi serta dilaporkan keuangan pada periode yang bersangkutan" [8].

Berdasarkan penjelasan di atas penulis menyimpulkan bahwa pencatatan akuntansi terdiri dari dua pencatatan yaitu metode Cash Basic dimana penerimaan dan pengeluaran kas di catat saat itu juga pada saat taransaksi dan Accrual Basic terjadi dimana pencatatan akuntansi diakui langsung ketika terjadi transaksi, walaupun belum terjadi penerimaan atau pengluaran kas.

\section{Proses Akuntansi}

Definisi proses akuntansi menurut Supriyati yaitu, "proses akuntansi adalah tahapantahapan di dalam siklus akuntansi mulai dari pencatatan, klasifikasi, pengikhtisaran sampai dengan pelaporan"[9].

Skema proses akuntansi menurut Supriyati adalah sebagai berikut:

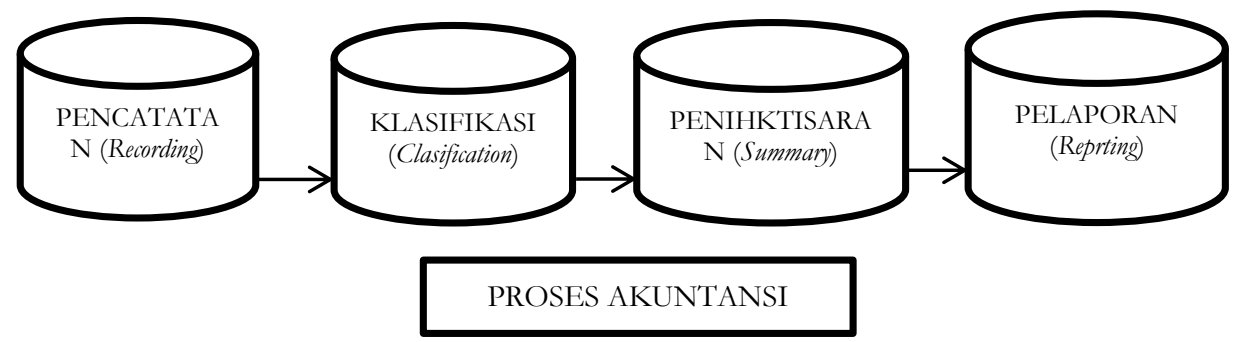

Gambar 1 Proses Akuntansi (Supriyati)[9].

\section{Metode}

\section{Unit Penelitian}

Definisi unit analisis menurut Supriyati, "unit analisis adalah tempat dimana penulis adalah tempat dimana peneliti melakukan penelitian"[12].

Definisi unit analisis menurut Arikunto "unit analisis dalam penelitian adalah suatu tertentu yang di perhitungkan sebagai subjek penelitian"[13].

Berdasarkan definisi di atas, penulis menyimpulkan bahwa unit analisis adalah mengumpulkan data-data dan mengolahnya untuk membantu penelitian yang dilakukan penulis dan dapat digunakan peneliti.

\section{Jenis Penelitian}

Peneliti menggunakan jenis penelitian akademik. Definisi penelitian akademik menurut Sugiyono "penellitian akademik merupakan penelitian yang akan dilakukan oleh mahasiswa dan merupakan sarana edukatif sehingga lebih mementingkan edukasi internal (cara yang harus betul)"'[14].

\section{Jenis Data}

Menurut Sugiyono, jenis data terbagi menjadi dua yaitu, "data kuantatif adalah penelitian yang jenis datanya berupa langka atau data kualitatif yang diangkakan data kualitatif adalah penelitian yang jenis datanya dalam bentuk kata, kalimat dan gambar"'[14].

Jenis data yang digunakan peneliti dalam penelitian ini adalah data kuantitatif karena informasi yang diperoleh dalam penelitian berupa angka. 
Nama Penulis : Dony Waluya Firdaus, Sheylla Febryani

Judul : Perancangan Sistem Informasi Akuntansi Harga

Pokok Produksi Pada Distro Viking Cimahi

Dengan Menggunakan Software Microsoft Visual

Basic 2008 Dan Database MySQL
Jurnal @ is The Best

Vol. 04 No. 01. Juni 2019: Hal 366-380

P-ISSN : 2252-9853

\section{Metode Penelitian}

Definisi metode penelitian menurut Sugiyono, "metode penelitian pada dasarnya merupakan cara ilmiah untuk mendapatkan data dengan tujuan dan kegunaan tertentu"[14].

Definisi lain menurut Supriyati, "metode penelitian adalah tatacara bagaimana suatu penelitian dilaksanakan".[12]

Berdasarkan definisi di atas, penulis menyimpulkan bahwa metode penelitian adalah cara mendapatkan informasi dan data untuk penelitian. Metode penelitian yang peneliti gunakan adalah metode survei.

\section{Teknik Pengumpulan Data}

Definisi teknik pengumpulan data menurut Sugiyono, "teknik pengumpulan data merupakan langkah yang paling strategis dalam penelitian, karna tujuan dari penelitian adalah mendapatkan data"[15]. Berikut merupakan teknik pengumpulan data yang digunakan peneliti yaitu sebagai berikut :

\section{Wawancara}

Pengertian wawancara menurut Sugiyono yaitu "wawancara digunakan sebagai teknik pengumpulan data apabila ingin melakukan studi pendahuluan untuk menemukan masalah yang harus diteliti, dan jasa apabila peneliti ingin mengetahui hal-hal dari responden yang telah mendalam dan jumlah responnya sedikit/kecil"'[14]. Definisi lain dari wawancara menurut Supriyati "wawancara adalah teknik pengumpulan data melalui pertanyaan yang diajukan secara lisan kepada responden"'[12].

Penelitian dengan wawancara dan bertatap muka langsung dengan para owner di Distro Viking Cimahi mengenai prosedur, dokumen tentang harga pokok peroduksi dan hal lainnya.

\section{Pengamatan (Observation)}

"Pengamatan yaitu kegiatan menggunakan satu indra atau lebih seperti melihat, mendengar, mencium, mengecap dan meraba secara seksama untuk mendapatkan dokumen atau makna dari suatu yang diamati”[16].

Berdasarkan dokumen yang dikumpulkan, penulis melakukan pengamatan pada dokumen untuk mengupas informasi. Observasi juga dilakukan karena peneliti melakukan penelitian langsung ke Distro Viking Cimahi dan melakukan pengamatan pada bagian produksi.

\section{Metodologi Rekaya Perangkat Lunak}

Definisi metodologi pengembangan sisitem menurut Jogiyanto "metodologi pengembangan sistem berarti adalah metode-metode, prosedur-prosedur konsep-konsep, aturanaturan dan postulat-postulat yang akan digunakan untuk mengembangkan suatu sistem informasi' [17].

Definisi lain menurut Tata sutarbi "metodologi pengembangan sistem adalah metode, prosedur, konsep pekerjaan dan aturan-aturan untuk mengembangkan suatu sistem informasi”'[3].

Berdasarkan definisi-definisi diatas penulis menyimpulkan bahwa metodologi adalah prosedir atau konsep untuk menyempurkan dan mengembangkan sistem yang penulis gunakan adalah metodologi mengembangkan sistem yang beriorentasi pada pengelolaan data, laporan keuangan dengan menyimpan data metodologi pengembangan sistem yang digunakan adalah: 
Nama Penulis : Dony Waluya Firdaus, Sheylla Febryani

Judul : Perancangan Sistem Informasi Akuntansi Harga

Pokok Produksi Pada Distro Viking Cimahi

Dengan Menggunakan Software Microsoft Visual

Basic 2008 Dan Database MySQL
Jurnal @ is The Best

Vol. 04 No. 01. Juni 2019: Hal 366-380

P-ISSN : 2252-9853

\section{A. Metodologi yang Beriorentasi keluaran}

Definisi metodoligi yang beriorentasi keluaran menurut Tata Sutarbi adalah "metodologi ini disebut juga metodologi tradisional, diperkenalkan sekitar tahun 1960 dengan memberikan tahapan dalam pengmbangan sisiten tanpa dibeli dengan teknik dan piranti yang memadai, seperti cara menganalisis menggambarkan sistem sehingga sering juga disebut metodologi system life cycle (SDLC)'[3].

\section{B. Metodologi yang Berorientasi Proses}

Definisi metodologi yang berorientasi proses menurut Tata Sutarbi, "Metodologi ini disebut juga dengan metodologi struktur analisis desain"'[3].

\section{Metodologi yang Berorientasi Data}

Definisi metodologi yang berorientasi data menurut Tata Sutarbi, "Metodologi ini disebut model informasi alat yang digunakan untuk membuat model Entry Relational Diagram (ERD)"'[3].

\section{Lokasi Penelitian}

Penulis melakukan penelitian pada perusahaan yang bergerak di bidang manufaktur yang bernama Distro Viking Cimahi yang berlamat Distro Viking Cimahi yang beralamat di Jl Bunderan LW Gajah no.165 (Samping Apotek Binangkit) Cimahi - Bandung. Peneliti melakukan penelitian harga pokok produksi produk berdasarkan pesanan.

\section{Hasil Dan Pembahasan}

\section{Struktur Organisasi Usulan}

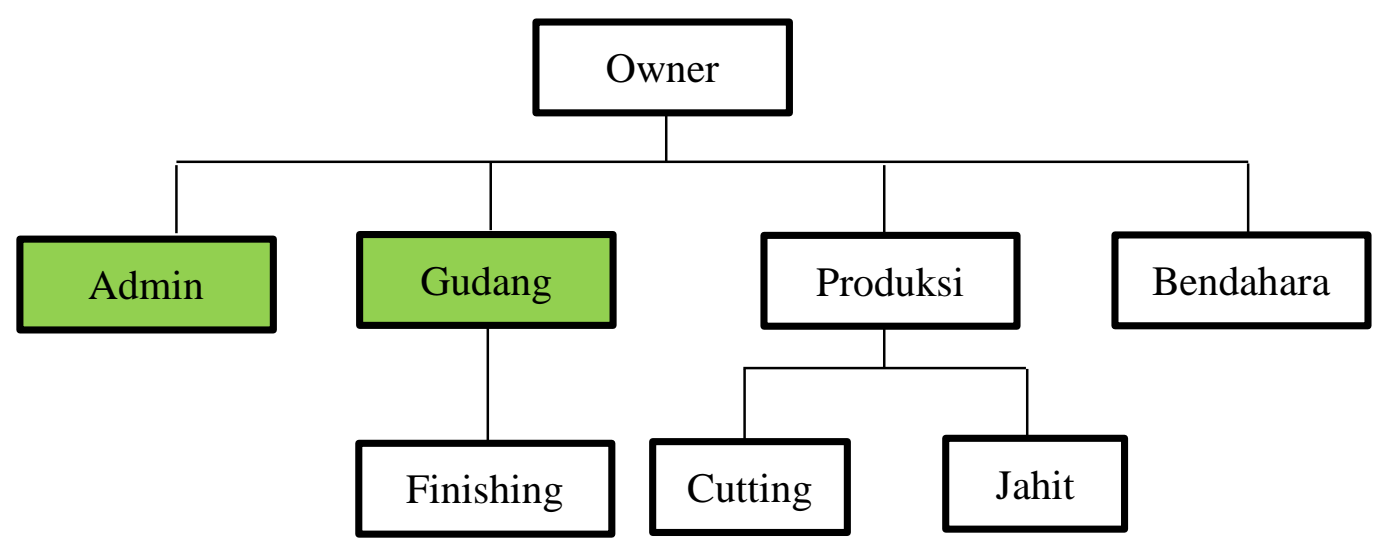

Keterangan:

Bagian yang penulis usulkan

\section{Gambar 2 Struktur Menu Usulan}


Nama Penulis : Dony Waluya Firdaus, Sheylla Febryani

Judul : Perancangan Sistem Informasi Akuntansi Harga

Pokok Produksi Pada Distro Viking Cimahi

Dengan Menggunakan Software Microsoft Visual

Basic 2008 Dan Database MySQL
Jurnal @ is The Best

Vol. 04 No. 01. Juni 2019: Hal 366-380

P-ISSN : 2252-9853

\section{Perancangan Model Sistem yang Diusulkan}

Tabel 1 Perbandingan Sistem yang Berjalan dengan Sistem yang Diusulkan

\begin{tabular}{|l|l|l|l|}
\hline $\mathbf{N}$ & Penjelasa & \multicolumn{1}{|c|}{ Sistem yng } & \multicolumn{1}{c|}{ Sistem yang Diusulkan } \\
$\mathbf{0}$ & \multicolumn{1}{|c|}{$\mathbf{n}$} & \multicolumn{1}{|c|}{ Berjalan } & \\
\hline 1 & Sistem & Siklus akuntansi & Penulis akan membuat sistem informasi akuntansi harga \\
& Informasi & belum & pokok produksi yang sesuai dengan standar akuntansi \\
& Akuntansi & memenuhi & keuangan, yaitu dengan membuat jurnal umum, buku besar, \\
& standar akuntansi & & \\
& biaya & & \\
\hline
\end{tabular}

\section{Diagram Konteks Usulan}

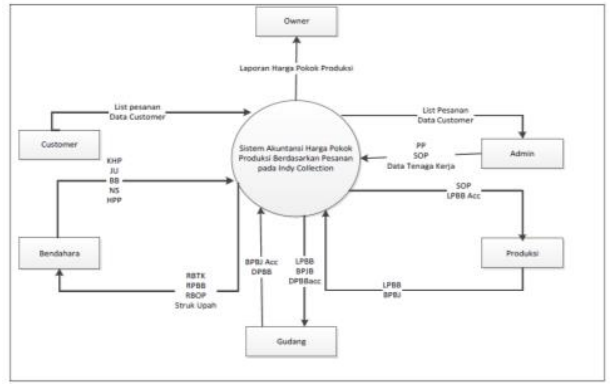

Gambar 3 Diagram Konteks Usulan

\begin{tabular}{ll}
\multicolumn{2}{l}{ Keterangan: } \\
A. & PP \\
B. & SOP \\
C. & LPBB \\
D. & DPBB \\
E. & LPBBacc \\
F. & BPBJ \\
G. & BPJBacc \\
H. & RPBB \\
I. & RBTK \\
J. & RBOP \\
K. & KHP \\
L. & JU \\
M. & BB \\
N. & NS \\
O. & HPP \\
P. & FP
\end{tabular}

\footnotetext{
$=$ Penerimaan Pesanan.

$=$ Surat Order Produksi.

$=$ List Permohonan Bahan Baku.

$=$ Daftar Pembelian Bahan Baku.

$=$ List Permohonan Bahan Baku disetujui.

$=$ Bukti Penyerahan Bahan Jadi.

$=$ Bukti Penyerahan Bahan Baku disetujui.

= Rincian Pemakaian Bahan Baku.

$=$ Rincian Biaya Tenaga Kerja.

$=$ Rincian Biaya Overhead Pabrik.

= Kartu Harga Pokok.

= Jurnal Umum

$=$ Buku Besar.

$=$ Neraca Saldo.

= Laporan Harga Pokok Produksi.

$=$ Faktur
} 
Nama Penulis : Dony Waluya Firdaus, Sheylla Febryani

Judul

: Perancangan Sistem Informasi Akuntansi Harga

Pokok Produksi Pada Distro Viking Cimahi

Dengan Menggunakan Software Microsoft Visual

Basic 2008 Dan Database MySQL

4. DFD (Data Flow Diagram) Level 0 Sistem yang Diusulkan

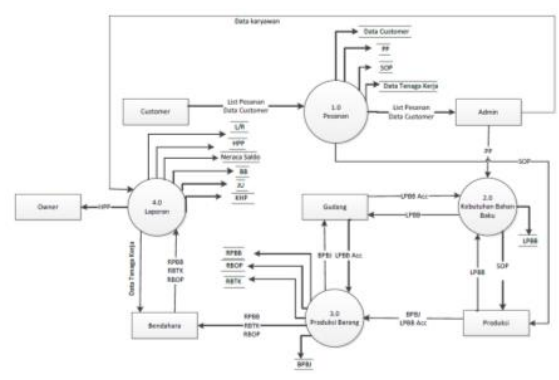

Gambar 4 Data Flow Diagram Level 0 Sistem yang Diusulkan

5. DFD (Data Flow Diagram) Level 1 Sistem yang Diusulkan

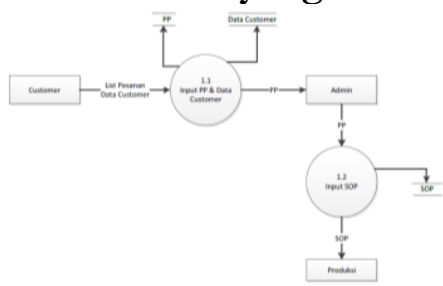

Gambar 5 Data Flow Diagram Level 1 Sistem yang Diusulkan

6. Bagan Alir yang Diusulkan

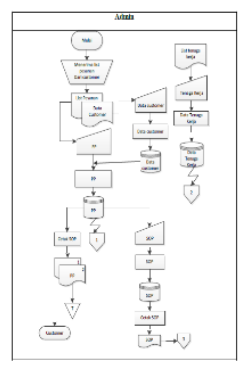

Gambar 6 Bagan Alir Sistem Admin yang Diusulkan

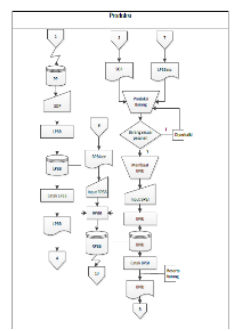

Gambar 7 Bagan Alir Sistem Produksi yang Diusulkan 
Nama Penulis : Dony Waluya Firdaus, Sheylla Febryani

Judul
: Perancangan Sistem Informasi Akuntansi Harga

Pokok Produksi Pada Distro Viking Cimahi

Dengan Menggunakan Software Microsoft Visual

Basic 2008 Dan Database MySQL
Jurnal @ is The Best Vol. 04 No. 01. Juni 2019: Hal 366-380

P-ISSN : 2252-9853

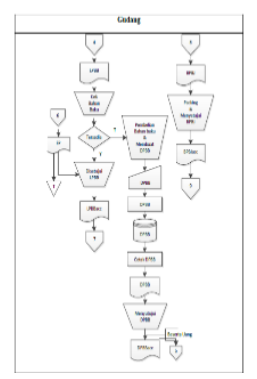

Gambar 8 Bagan Alir Gudang yang Diusulkan

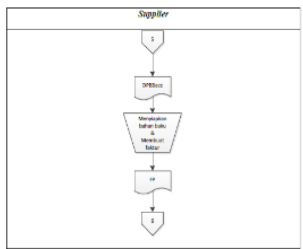

Gambar 9 Bagan Alir Sistem Suplier yang Diusulkan

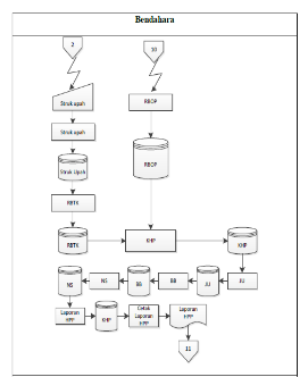

Gambar 10 Bagan Alir Sistem Bendahara yang Diusulkan

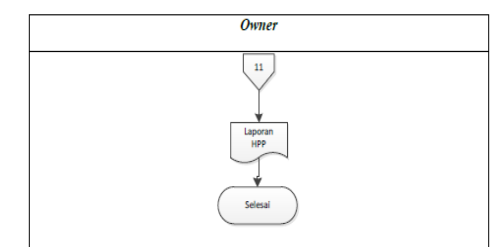

Gambar 11 Bagan Alir Sistem Owner yang Diusulkan 
Nama Penulis : Dony Waluya Firdaus, Sheylla Febryani

Judul : Perancangan Sistem Informasi Akuntansi Harga

Pokok Produksi Pada Distro Viking Cimahi

Dengan Menggunakan Software Microsoft Visual

Basic 2008 Dan Database MySQL
Jurnal @ is The Best Vol. 04 No. 01. Juni 2019: Hal 366-380

P-ISSN : 2252-9853

\section{Perancangan Basis Data}

Normalisasi yang Diusulkan

\section{PP Dalam Bentuk Unormal}

\section{Penerimaan Pesanan}

\begin{tabular}{|c|c|c|c|c|c|c|c|c|c|c|c|c|c|}
\hline No PP & Tanggal PP & Kode Customer & Nama Customer & Alamat & No Hp & Kode Baju & Nama Baju & & ga Baju & $\begin{array}{c}\text { Jumla } \\
\mathrm{h}\end{array}$ & Spesifikasi & & Cotal \\
\hline PP01 & $17 / 08 / 2018$ & cust 01 & Sheylla & Bandung & 878787009 & BJ01 & Jersey & $\mathrm{Rp}$ & 100.000 & 24 & & $\mathrm{Rp}$ & 2.400 .000 \\
\hline & & & & & & BJ02 & $\begin{array}{l}\text { Kaos Persib } \\
\text { Biru }\end{array}$ & $\mathrm{Rp}$ & 80.000 & 12 & & $\mathrm{Rp}$ & 960.000 \\
\hline
\end{tabular}

Tabel 2 PP Dalam Bentuk Normal Satu ke (1-NF)

\begin{tabular}{|c|c|c|c|c|c|c|c|c|c|c|c|}
\hline No PP & Tanggal PP & Kode Customer & Nama Customer & Alamat & No Hp & Kode Baju & Nama Baju & Harga Baju & Jumlah & Spesifikasi & Total \\
\hline PP01 & $17 / 08 / 2018$ & cust 01 & Sheylla & Bandung & 878787009 & BJ01 & Jersey & $\begin{array}{l}\mathrm{Rp} \\
100.000\end{array}$ & 24 & & $\begin{array}{l}\mathrm{Rp} \\
2.400 .000 \\
\end{array}$ \\
\hline PP01 & $17 / 08 / 2018$ & cust01 & Sheylla & Bandung & & BJ02 & $\begin{array}{ll}\text { Kaos } & \text { Persib } \\
\text { Biru } & \\
\end{array}$ & $\begin{array}{l}\mathrm{Rp} \\
80.000\end{array}$ & 12 & & $\begin{array}{l}\mathrm{Rp} \\
960.000\end{array}$ \\
\hline
\end{tabular}

Tabel 3 PP Dalam Bentuk Normal ke Dua (2-NF)

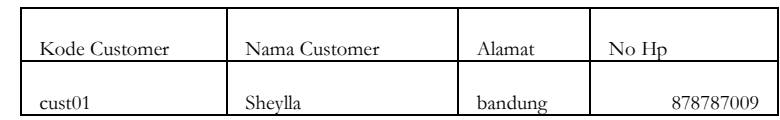

\begin{tabular}{|l|l|l|}
\hline Kode Baju & Nama Baju & Harga \\
\hline BJ01 & Jersey & Rp 100.000 \\
\hline BJ02 & Kaos Persib Biru & Rp 80.000 \\
\hline
\end{tabular}

\begin{tabular}{|l|r|r|l|l|}
\hline No PP & \multicolumn{1}{|l|}{ Tanggal PP } & Jumlah & Spesifikasi & Total \\
\hline PP01 & $17 / 08 / 2018$ & & & $\begin{array}{l}\text { Rp } \\
2.400 .000\end{array}$ \\
\hline PP01 & $17 / 08 / 2018$ & 24 & & $\begin{array}{l}\mathrm{Rp} \\
960.000\end{array}$ \\
\hline
\end{tabular}

Tabel 4 PP Dalam Bentuk Normal ke Dua (2-NF) Lanjutan 1

\begin{tabular}{|l|l|l|l|r|r|c|}
\hline No PP & Tanggal PP & Kode Baju & Nama Baju & Harga Baju & Jumlah & Total \\
\hline PP01 & $17 / 08 / 2018$ & Bj01 & Jersey & 100000 & 24 & $\begin{array}{c}\text { Rp } \\
2.400 .000\end{array}$ \\
\hline PP01 & $17 / 08 / 2018$ & Bj02 & $\begin{array}{l}\text { Kaos Persib } \\
\text { Biru }\end{array}$ & 80000 & 12 & $\begin{array}{c}\text { Rp } \\
960.000\end{array}$ \\
\hline
\end{tabular}

Tabel 5 PP Dalam Bentuk Mormal ke Tiga (3-NF)

\begin{tabular}{|l|l|l|l|}
\hline No PP & Tanggal PP & Kode Customer & Total \\
\hline PP01 & $17 / 082018$ & cust01 & Rp 2.400 .000 \\
\hline PP01 & $17 / 082018$ & cust01 & Rp 960.000 \\
\hline
\end{tabular}

Tabel 6 PP Dalam Bentuk Normal ke Tiga (3-NF) Lanjutan 1 
Nama Penulis : Dony Waluya Firdaus, Sheylla Febryani

Judul

: Perancangan Sistem Informasi Akuntansi Harga

Pokok Produksi Pada Distro Viking Cimahi

Dengan Menggunakan Software Microsoft Visual

Basic 2008 Dan Database MySQL

\begin{tabular}{|l|r|l|}
\hline Kode Baju & Jumlah & Spesifikasi \\
\hline BJ01 & 24 & Rp 2.400 .000 \\
\hline BJ02 & 12 & Rp $\quad 960.000$ \\
\hline
\end{tabular}

8. Perancangan Antarmuka

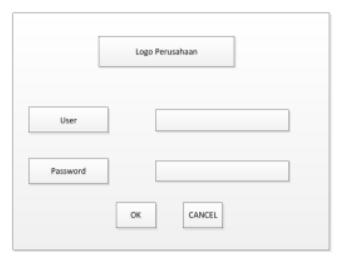

Gambar 12 Tampilan Perancangan Antarmuka Login

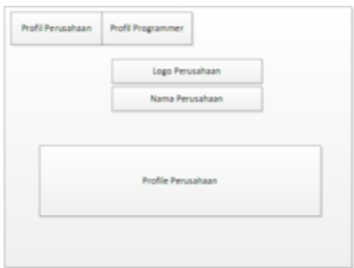

Gambar 13 Tampilan Perancangan Antarmuka Profil Perusahaan

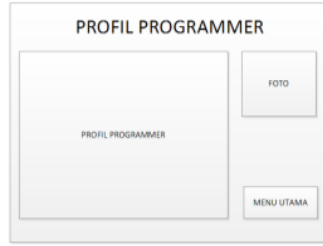

Gambar 14 Tampilan Perancangan Antarmuka Profil Programmer

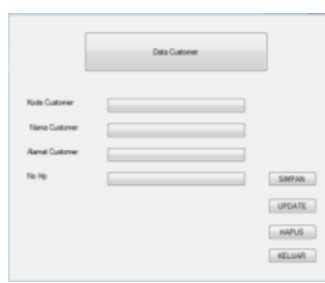

Gambar 15 Tampilan Perancangan Antarmuka Customer

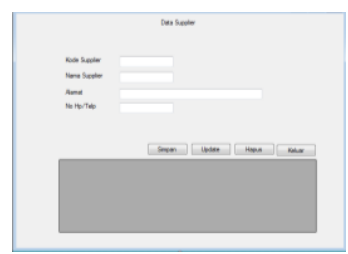

Gambar 16 Tampilan Perancangan Antarmuka Supplier 
Nama Penulis : Dony Waluya Firdaus, Sheylla Febryani

Judul
: Perancangan Sistem Informasi Akuntansi Harga

Pokok Produksi Pada Distro Viking Cimahi

Dengan Menggunakan Software Microsoft Visual

Basic 2008 Dan Database MySQL
Jurnal @ is The Best Vol. 04 No. 01. Juni 2019: Hal 366-380

P-ISSN : 2252-9853

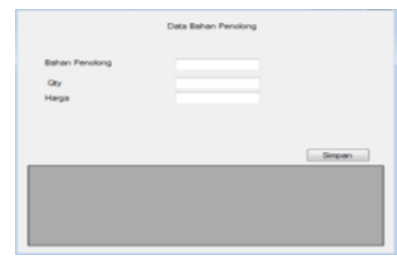

Gambar 17 Tampilan Perancangan Antarmuka Bahan Penolong

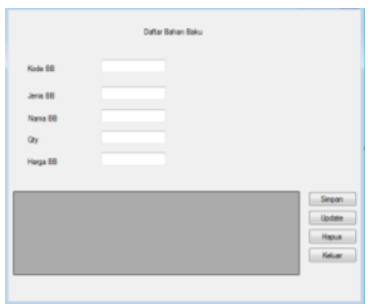

Gambar 18 Tampilan Perancangan Antarmuka Bahan Baku

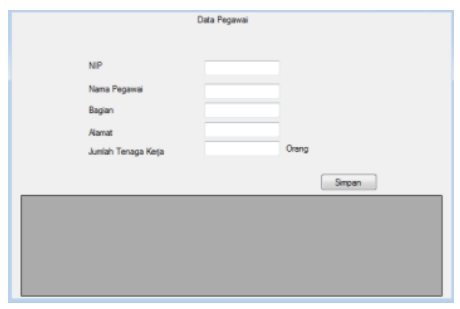

Gambar 19 Tampilan Perancangan Antarmuka Pegawai

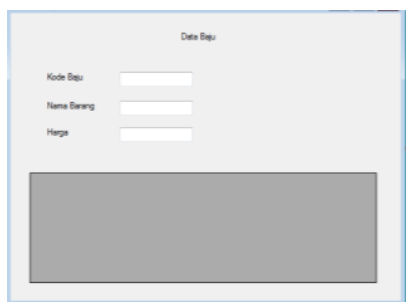

Gambar 20 Tampilan Perancangan Antarmuka Data Baju

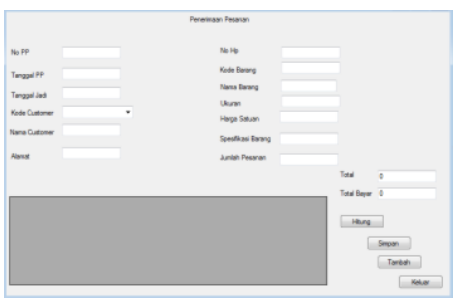

Gambar 21 Tampilan Perancangan Antarmuka PP 
Nama Penulis : Dony Waluya Firdaus, Sheylla Febryani

Judul
: Perancangan Sistem Informasi Akuntansi Harga

Pokok Produksi Pada Distro Viking Cimahi

Dengan Menggunakan Software Microsoft Visual

Basic 2008 Dan Database MySQL
Jurnal @ is The Best Vol. 04 No. 01. Juni 2019: Hal 366-380

P-ISSN : 2252-9853

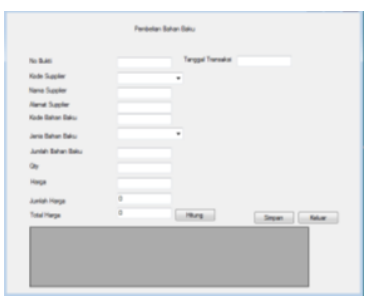

Gambar 22 Tampilan Perancangan Antarmuka Pada PBB

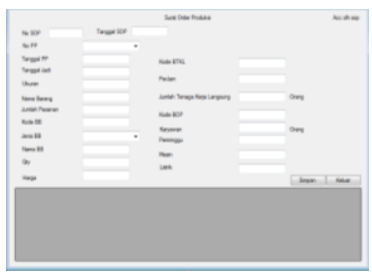

Gambar 23 Tampilan Perancangan Antarmuka Pada SOP

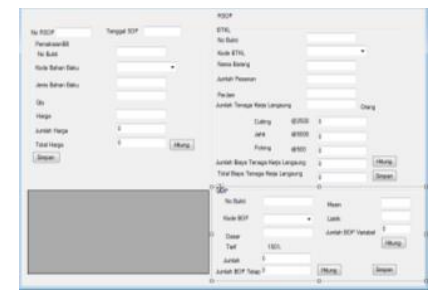

Gambar 24 Tampilan Perancangan Antarmuka Pada RSOP

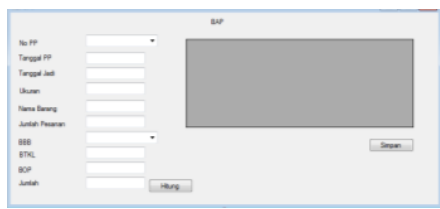

Gambar 25 Tampilan Perancangan Antarmuka Pada BAP

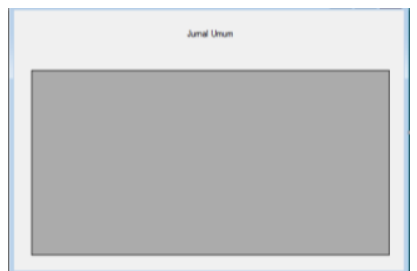

Gambar 26 Tampilan Perancangan Antarmuka Pada JU 
Nama Penulis : Dony Waluya Firdaus, Sheylla Febryani

Judul

: Perancangan Sistem Informasi Akuntansi Harga

Pokok Produksi Pada Distro Viking Cimahi

Dengan Menggunakan Software Microsoft Visual

Basic 2008 Dan Database MySQL
Jurnal @ is The Best Vol. 04 No. 01. Juni 2019: Hal 366-380

P-ISSN : 2252-9853

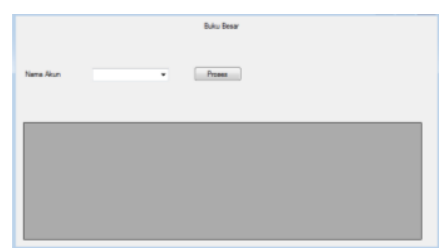

Gambar 27 Tampilan Perancangan Antarmuka Pada BB

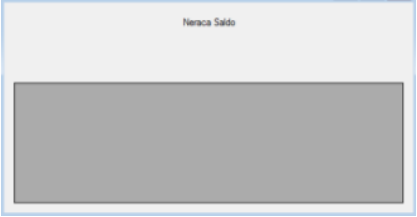

Gambar 28 Tampilan Perancangan Antarmuka Pada NS

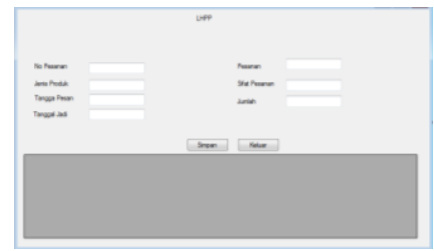

Gambar 29 Tampilan Perancangan Antarmuka Pada LHPP

9. Perancangan Diagram Relaso Entitas (Entry Relationship Diagram) Yang Diusulkan Pada Distro Viking Cimahi

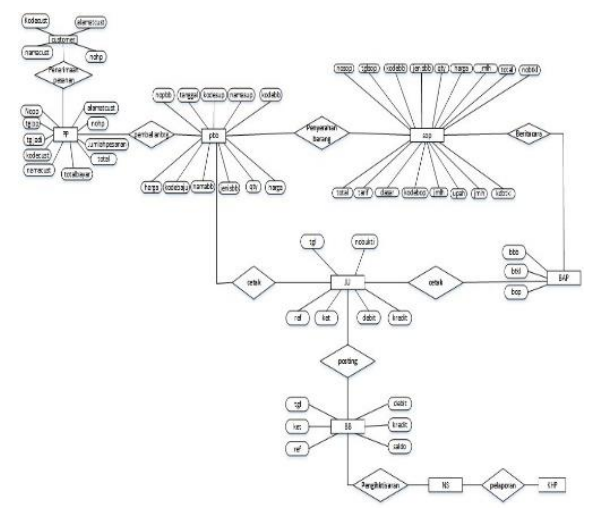

Gambar 30 Entry Relationship Diagram Usulan 
Nama Penulis : Dony Waluya Firdaus, Sheylla Febryani

Judul : Perancangan Sistem Informasi Akuntansi Harga

Pokok Produksi Pada Distro Viking Cimahi

Dengan Menggunakan Software Microsoft Visual

Basic 2008 Dan Database MySQL
Jurnal @ is The Best

Vol. 04 No. 01. Juni 2019: Hal 366-380

P-ISSN : 2252-9853

\section{Penutup}

Setelah melakukan penelitian bahwa Distro Viking Cimahi menggunakan metode pesanan untuk menentukan harga pokok produksi, selain itu pencatatan akuntansinya masih manual, sehingga akan memungkinkan terjadinya kesalahan dalam pencatatan dan mengakibatkan keterlambatan pelaporan. Maka dari itu penulis membuatkan suatu system informasi untuk memudahkan pencatatan laporan keuangan juga agar lebih mempercepat waktu pekerjaan perusahaan dengan menggunakan system berbasis computer.

\section{Daftar Pustaka}

[1] A. Susanto, Sistem Informasi Akuntansi. Bandung: Lingga Jaya, 2013.

[2] Subban, Perancangan Sistem Informasi. Jakarta: Elekmedia Komptindo, 2012.

[3] T. Sutarbi, Analisis Sistem Informasi. Yogyakarta: Andi Offset, 2012.

[4] Unika, Sistem Informasi. Yogyakarta: Perpustakaan Universitas Yogyakarta, 2017.

[5] L. Puspitawati, D. Anggadini, and S. Dewi, Sistem Informasi Akuntansi. Yogyakarta: Graha Ilmu.

[6] M. B. Rommey and P. J. Steinbarth, Accounting Information System, Edisi 9. Jakarta: Salemba Empat, 2011.

[7] Bastian, Akuntansi Sektor Publik. Malang: Universitas Muhammadiyah, 2014.

[8] I. A. Indonesia, Standar Akuntansi Keuangan. Jakarta: Salemba Empat, 2009.

[9] Supriyati, Belajar Akuntansi Dasar. Bandung: Labkat Press Unikom, 2014.

[10] Soemarso, Pengantar Akuntansi. Bandung: Perpustakaan UNIKOM, 2009.

[11] Mulyadi, Akuntansi Biaya, Edisi 5. Yogyakarta: UPP-STIM YKPN, 2012.

[12] Supriyati, Metode Penelitian. Bandung: Labkat Press Unikom, 2011.

[13] A. Suharsimi, Prosedur Penelitian Suatu Pendekatan Praktik. Jakarta: PT.Rineka Cipta, 2010.

[14] Sugiyono, Metode Penelitian Kuantitatif, Kualitatif, dan R\&D. Bandung: Alfabeta, 2011.

[15] Sugiyono, Metode Penelitian Kuantitatif, Kualitatif, dan R\&D. Bandung: Alfabeta, 2010.

[16] Johny, Pengertian Pengamatan dan Jenis-Jenis. Bandung: Perpustakaan Maya, 2015.

[17] Jogiyanto, Sistem Informasi Akuntansi. Jakarta: Citra Harta Prima, 2012. 